\title{
PENGEMBANGAN MEDIA CERITA BERGAMBAR UNTUK MELATIH KEMAMPUAN BERPIKIR KREATIF SISWA PADA MATERI PECAHAN KELAS II
}

\author{
Ari Mawanto $^{1}$, Tatag Yuli Eko Siswono ${ }^{2}$, Agung Lukito $^{3}$ \\ ${ }^{1,2,3}$ Universitas Negeri Surabaya, Jalan Lidah Wetan, Kota Surabaya, Indonesia \\ ari.18076@mhs.unesa.ac.id
}

\begin{abstract}
This research is conducted because there was no learning media used in school learning activities, especially fractions material, learning resources only use teacher books and student books, that learning uses lecture methods so that it seems still conventional, the teachers only focus on learning outcomes without regard to students' creative thinking abilities. The purpose of this study is to produce a decent pictorial story media and describe students' creative thinking abilities after learning to use pictorial story media on fractions of grade II elementary school. This research is a type of development research based on the stages of the ADDIE model including analyze, design, develop, implement, and evaluate. The research subjects at the stage of trials consisted of 20 students and the implementation phase consisted of 27 students at SDN Lontar II Surabaya in the academic year 2019/2020. This research produces a decent pictorial story media that meets the criteria of validity, practicality, and effectiveness. The ability of creative thinking students at the stage of trials increase become $80 \%$ and the mastery of classical learning by $85 \%$, while at the stage of the implementation of creative thinking abilities progressed by $85 \%$ and the mastery of classical learning by $88.89 \%$. Thus, this pictorial story media can be used as an alternative learning medium to train students' creative thinking skills on fractions material.
\end{abstract}

\section{Keywords: Pictorial Story Media, Creative Thinking, Fractions, Second Graders}

\begin{abstract}
Abstrak
Penelitian ini dilakukan karena belum ada media pembelajaran yang digunakan pada kegiatan pembelajaran di sekolah khususnya materi pecahan, sumber belajar hanya menggunakan buku guru dan buku siswa, pembelajaran hanya menggunakan metode ceramah sehingga terkesan masih bersifat konvensional, guru hanya memfokuskan pada hasil belajar tanpa memperhatikan kemampuan berpikir kreatif siswa. Tujuan penelitian ini adalah menghasilkan media cerita bergambar yang layak dan mendeskripsikan kemampuan berpikir kreatif siswa setelah diterapkan pembelajaran menggunakan media cerita bergambar pada materi pecahan kelas II SD. Penelitian ini merupakan jenis penelitian pengembangan berdasarkan tahapan-tahapan model ADDIE meliputi analyze, design, develop, implement, dan evaluate. Subjek penelitian pada tahap uji coba terdiri atas 20 siswa dan tahap implementasi terdiri atas 27 siswa di SDN Lontar II Surabaya tahun pelajaran 2019/2020. Penelitian ini menghasilkan media cerita bergambar yang layak yaitu memenuhi kriteria kevalidan, kepraktisan, dan keefektifan. Kemampuan berpikir kreatif siswa pada tahap uji coba mengalami kemajuan sebesar $80 \%$ dan ketuntasan belajar klasikal sebesar $85 \%$, sedangkan pada tahap implementasi kemampuan berpikir kreatif mengalami kemajuan sebesar $85 \%$ dan ketuntasan belajar klasikal sebesar 88,89\%. Dengan demikian, media cerita bergambar ini dapat digunakan sebagai alternatif media pembelajaran untuk melatih kemampuan berpikir kreatif siswa pada materi pecahan.
\end{abstract}

Kata kunci: Media Cerita Bergambar, Berpikir Kreatif, Pecahan, Siswa kelas II

\section{PENDAHULUAN}

Kemajuan teknologi dan informasi pada zaman ini tidak bisa dipungkiri berasal dari hasil kemampuan berpikir kreatif manusia. Manusia memiliki akal, budi, dan karsa untuk melahirkan inovasi terhadap pengetahuan dan menerapkannya agar dapat memecahkan masalah yang ditemui. Kemampuan berfikir kreatif seseorang memacu keinginan agar hidupnya lebih baik dan sejahtera pada kondisi lingkungan yang sangat terbatas. Oleh sebab itu, dibutuhkan kemampuan untuk berpikir kreatif dalam mengatasinya (Siswono, 2018)

Berpikir kreatif merupakan suatu proses yang digunakan ketika kita


mendatangkan/memunculkan suatu ide baru (Siswono \& Rosyidi, 2005). Berpikir kreatif juga dapat diartikan sebagai suatu kombinasi dari berpikir logis dan berpikir divergen yang didasarkan pada intuisi tetapi masih dalam kesadaran (Pehkonen, 1997). Ketika seseorang menerapkan berpikir kreatif, pemikiran divergen menghasilkan banyak ide-ide. Hal ini akan berguna dalam menemukan penyelesaiannya. Dalam berpikir kreatif dua bagian otak akan sangat diperlukan. Keseimbangan antara logika dan kreatif sangat penting. Jika salah satu menempatkan deduksi logis terlalu banyak, maka kreatif akan terabaikan. Dengan demikian untuk memunculkan pemikiran kreatif diperlukan kebebasan berpikir tidak di bawah kontrol atau tekanan.

Mengingat begitu pentingnya faktor pemikiran kreatif dalam menentukan keunggulan suatu bangsa, mendorong berbagai pihak, termasuk institusi pendidikan, untuk mengembangkannya. Saat ini, pengembangan kreativitas telah menjadi salah satu fokus pembelajaran, termasuk pembelajaran matematika. Secara eksplisit, berpikir kreatif juga menjadi salah satu standar kelulusan siswa terkait pembelajaran matematika. Dikehendaki lulusan mempunyai kemampuan berpikir logis, analitis, sistematis, kritis, dan kreatif, serta mempunyai kemampuan bekerja sama. Kemampuan ideal demikian diharapkan dapat dicapai melalui proses pembelajaran yang dirancang dengan baik (Mahmudi, 2009).

Salah satu topik dalam matematika yang berpotensi sebagai sarana untuk mengembangkan kemampuan berpikir kreatif adalah topik pecahan. Potensi demikian dimiliki topik ini karena terdapat beragam representasi untuk menyajikan topik ini. Beragam representasi ini dapat menstimulasi kemampuan berpikir fleksibel siswa dalam mengomunikasikan ide-ide matematika terkait pecahan. Sementara kemampuan berpikir fleksibel merupakan salah satu aspek berpikir kreatif.

Hasil observasi yang dilakukan peneliti kepada guru Sekolah Dasar di SDN Lontar II Surabaya, diperoleh hasil observasi yang mengacu pada aspek media pembelajaran dan evaluasi pembelajaran yaitu: (1) belum ada media pembelajaran yang digunakan pada kegiatan pembelajaran di sekolah khususnya materi pecahan; (2) hanya menggunakan buku guru dan buku siswa untuk mengajarkan pecahan; (3) pembelajaran hanya menggunakan metode ceramah sehingga terkesan masih bersifat konvensional; (4) guru hanya memfokuskan pada hasil belajar tanpa memperhatikan kemampuan berpikir kreatif siswa; dan (5) kemampuan berpikir kreatif belum pernah diukur. Salah satu penyebab dari keadaan tersebut adalah kurangnya media pembelajaran yang digunakan dalam menyampaikan materi pecahan terbatas bahkan belum ada. Oleh karena itu media yang digunakan harus disediakan agar dapat menghasilkan tujuan pembelajaran yang ingin dicapai, salah satu media yang dapat digunakan adalah cerita bergambar yang terkait dengan materi pecahan. Beberapa permasalahan tersebut harus segera diatasi agar siswa mampu mengembangkan kemampuan berpikir kreatif dengan difasilitasi oleh media agar pembelajaran lebih menarik dan mencapai tujuan pembelajaran yang diharapkan.

Buku cerita bergambar adalah media yang mampu menampilkan gambar sebagai contoh dalam kehidupan sehari-hari. Dengan cerita sebagai contoh, disertai penjelasan dan ditambah dengan 
ilustrasi/gambar, anak diharapkan dapat mengenali bentuk-bentuk pecahan. Menurut Cianciolo (2000), buku bergambar dipandang cocok karena keunikan dari penyatuan teks dan ilustrasi/gambar. Selain itu, kelebihan buku bergambar menurut Cianciolo (2000) adalah memberikan perluasan pengalaman, minat, dan preferensi dari setting dan tema yang diangkat kepada pembaca.

Gambar-gambar dalam buku cerita anak-anak berkontribusi pada perkembangan bahasa anak serta pengembangan kreativitas, intelektual dan artistik pada anak. Dalam konteks ini, anak perlu lebih banyak berinteraksi dengan buku bergambar yang disiapkan dengan kepekaan seniman untuk berkontribusi pada perkembangan bahasa anak-anak (Ozsezer \& Canbazoglu, 2018, p. 206).

Beberapa penelitian pengembangan media cerita bergambar cukup banyak dilaksanakan. Salah satu penelitian telah dilaksanakan oleh Maulida (2018) yang berjudul "Pengembangan Bahan Bacaan Cerita Bergambar Berorientasi Pendidikan Karakter untuk Pembelajaran Membaca Siswa Kelas II SD” . Hasil penelitian menunjukkan bahwa kualitas produk bahan bacaan cerita bergambar berorientasi pendidikan karakter untuk pembelajaran membaca siswa kelas II SD termasuk dalam kategori baik, dengan rerata skor 4,3 dari rentang nilai 1-5. Aspek pembelajaran menunjukkan rerata skor 4,2; aspek isi rerata skor 4,8; aspek tampilan rerata skor 4,8. Hasil tes belajar siswa rata-rata nilai sudah mencapai ketuntasan. Penggunaan bahan bacaan ini berdampak baik terhadap ketuntasan belajar siswa. Dari 60 siswa, semua siswa mendapat nilai baik dan mencapai standar ketuntasan belajar minimal, yaitu memperoleh nilai 70. Dengan demikian, produk bacaan tersebut sudah layak digunakan pada saat pembelajaran membaca.

Berdasarkan hasil pengamatan di atas, maka dapat disimpulkan bahwa pembelajaran di sekolah membutuhkan sebuah media pembelajaran yang lebih mudah dipahami dan bisa digunakan kapan saja yaitu media cerita bergambar. Media yang akan dirancang oleh penulis digunakan sebagai penunjang dari buku pelajaran yang sudah ada. Dalam hal ini media dimaksudkan untuk melatih siswa agar memiliki kemampuan berpikir kreatif. Maka peneliti akan berupaya untuk menyelesaikan masalah tersebut dengan melakukan penelitian dengan mengembangkan media cerita bergambar untuk melatih kemampuan berpikir kreatif siswa.

Adapun tujuan penelitian ini adalah menghasilkan media cerita bergambar yang layak dan mendeskripsikan tingkat kemampuan berpikir kreatif siswa setelah diterapkan pembelajaran menggunakan media cerita bergambar pada materi pecahan kelas II SD. Manfaat yang diharapkan dari hasil penelitian ini adalah: (1) Bagi peneliti, penelitian ini bermanfaat untuk mengembangkan pengetahuan, meningkatkan wawasan penelitian, dan memperluas pengetahuan tentang pengembangan media pembelajaran; (2) Bagi guru, hasil penelitian ini bermanfaat agar media cerita bergambar dalam pembelajaran pecahan sebagai alternatif supaya kegiatan pembelajaran lebih menarik dan menyenangkan; (3) Bagi siswa, siswa lebih mudah dalam mempelajari pecahan dengan media cerita bergambar dan untuk melatih keterampilan berpikir kreatif.

Spesifikasi produk yang terdapat pada media cerita bergambar adalah sebagai berikut: (1) Media dihasilkan berbentuk buku cerita bergambar yang berjudul "Media Cerita Bergambar Pecahan 
Kelas II"; (2) Media cerita bergambar terdiri dari judul, kata pengantar, nama tokoh, daftar KI dan $\mathrm{KD}$, daftar isi, cerita bergambar, daftar pustaka, dan sinopsis buku; (3) Materi dalam media cerita bergambar mencakup bentuk-bentuk pecahan $\frac{1}{2}, \frac{1}{3}$, dan $\frac{1}{4}$; (4) Bahasa yang digunakan adalah bahasa formal yang bersifat komunikatif. Sesuai dengan usia siswa yaitu untuk siswa kelas II di Sekolah Dasar; (5) Produk yang dikembangkan dilengkapi dengan teks, gambar kartun dan warna yang menarik yang sesuai dengan materi yang dikembangkan; (6) Produk didesain dengan menggunakan teknik digital memanfaatkan program utama corel draw x7 dan didukung perangkat lunak lainya seperti chrome, Internet Download Manager, dll; (7) Dari segi ukurannya produk yang dihasilkan dicetak menggunakan kertas ukuran A5 dan dikemas menggunakan jilid spiral dengan ukuran kawat 5/16 inchi; dan (8) Cover menggunakan kertas art paper 210 gr dilapisi laminasi glossy, isinya full colour dengan menggunakan kertas art paper $150 \mathrm{gr}$.

\section{METODE}

Jenis penelitian ini adalah penelitian pengembangan. Sebagaimana yang dijelaskan Sugiyono (2018, p. 297), penelitian pengembangan merupakan penelitian yang digunakan untuk menghasilkan produk tertentu dan menguji keefektifan produk tersebut. Subjek pada penelitian pengembangan media cerita bergambar ini adalah siswa kelas II SDN Lontar II Kecamatan Sambikerep Kota Surabaya yang dilaksanakan pada semester genap tahun pelajaran 2019/2020. Prosedur dalam penelitian ini menggunakan tahapan model ADDIE meliputi tahap analyze, design, develop, implement, dan evaluate (Branch, 2009). Pada penelitian ini produk yang dikembangkan untuk mengetahui kevalidan, kepraktisan, dan keefektifan (Nieveen \& et.al., 1999). Instrumen pengumpul data terdiri atas lembar validitas media dan perangkat pembelajaran, lembar penilaian kepraktisan media oleh guru, lembar penilaian kepraktisan media oleh siswa, lembar angket respon siswa, tes hasil belajar, dan tes berpikir kreatif.

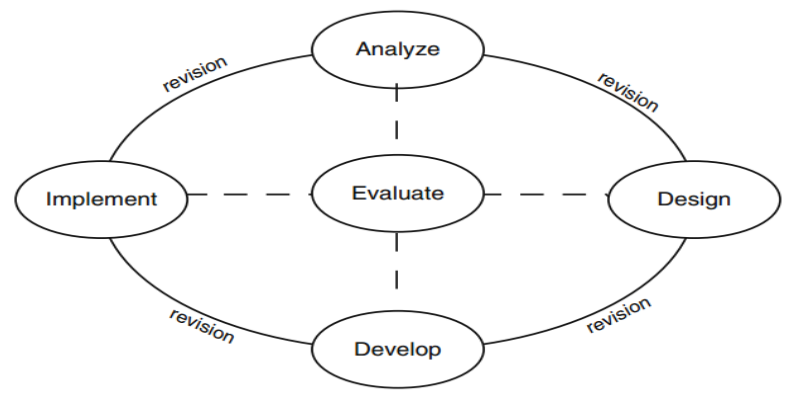

Gambar 1. Konsep model ADDIE

\section{HASIL}

Pengembangan media cerita bergambar ini menggunakan tahapan model ADDIE yang terdiri atas lima tahap pengembangan, yaitu analisis (analyze), desain (design), pengembangan (develop), implementasi (implement), dan evaluasi (evaluate). 


\section{Analisis (analyze)}

Pada tahap analisis, hasil observasi ditemui beberapa analisis masalah yang terjadi di SDN Lontar II Surabaya yaitu: (1) keterbatasan sumber belajar; (2) kurangnya pengetahuan dan keterampilan guru tentang cara yang dapat gunakan untuk mengembangkan media pembelajaran; dan (3) kurangnya motivasi belajar siswa dalam mengikuti kegiatan pembelajaran matematika. Solusi dari permasalahan tersebut dapat dilakukan dengan cara penyediaan fasilitas media pembelajaran yang memadai.

\section{Desain (design)}

Hasil pengembangan media cerita bergambar untuk pembelajaran matematika tentang materi pecahan untuk kelas II Sekolah Dasar adalah sebagai berikut:

\section{Sampul depan}

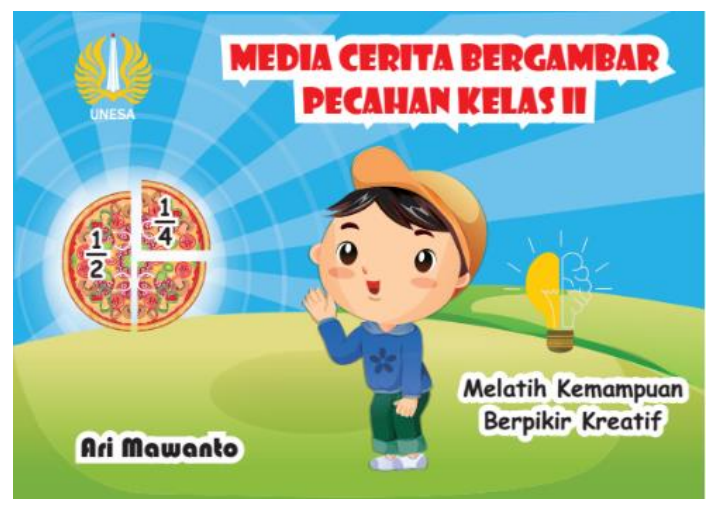

Gambar 2. Sampul depan media cerita bergambar

\section{Halaman pembuka Media}

Sebelum menampilkan isi media, peneliti menyajikan pengantar, petunjuk penggunaan media, Kompetensi Dasar (KD) sesuai dengan kurikulum 2013, daftar isi. Semua konten ini disajikan sebelum memulai isi media cerita bergambar yang menjelaskan materi pecahan.

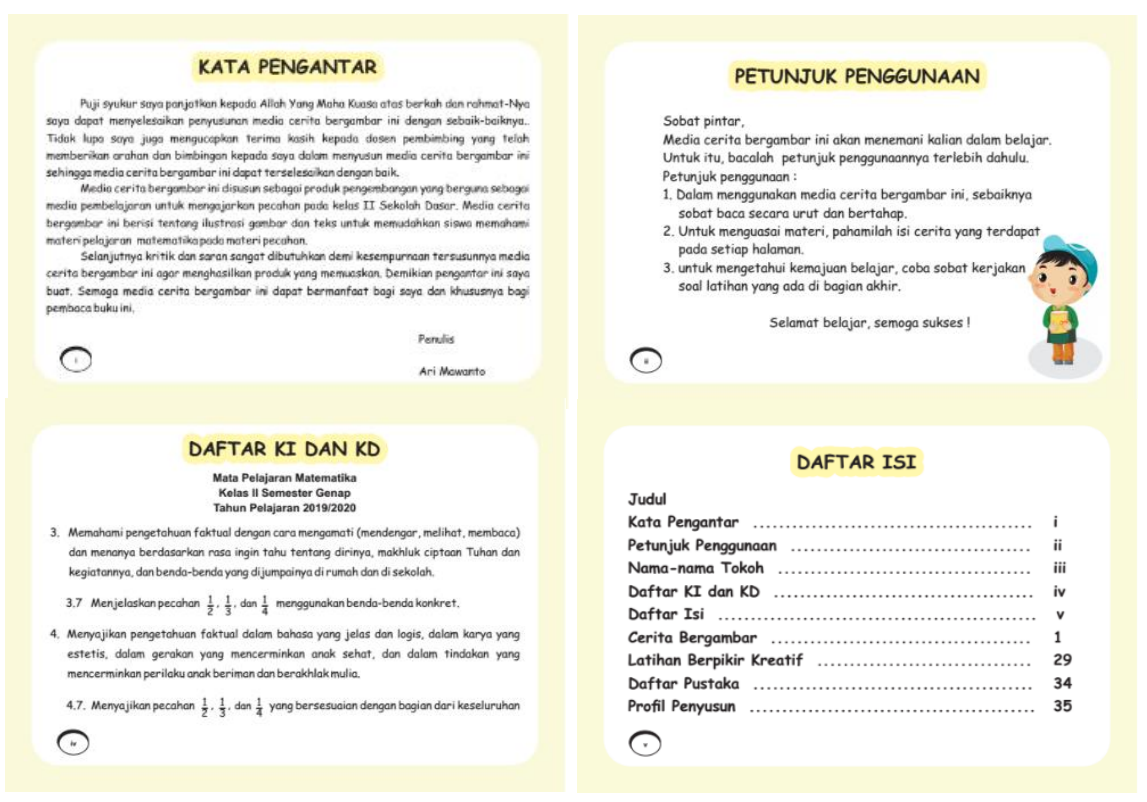

Gambar 3. Tampilan halaman pembuka 


\section{Halaman Isi Media Cerita Bergambar}

Isi media cerita bergambar dibuat secara urut berdasarkan materi pecahan yang mengacu pada tujuan pembelajaran. Bagian ini berisi halaman-halaman yang menjelaskan tentang pecahan.

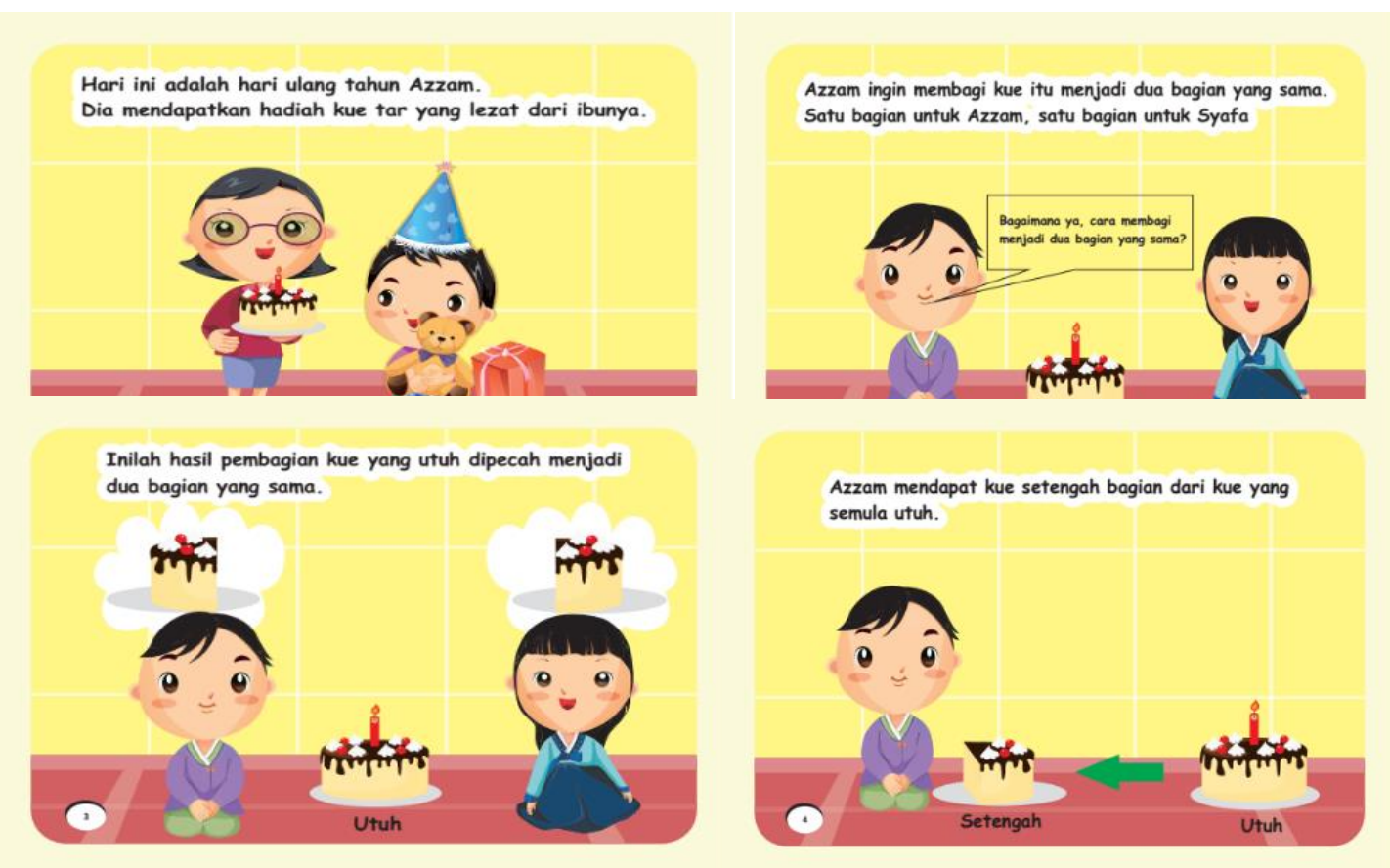

Gambar 4. Tampilan isi media

\section{Latihan Soal}

Untuk mengoptimalkan pemahaman siswa, peneliti memberikan kesempatan kepada siswa untuk latihan. Latihan diberikan di halaman akhir yang dikerjakan oleh siswa secara individual. Bentuk latihan ini disesuaikan dengan kompetensi yang dinyatakan dalam tujuan pembelajaran yang akan dicapai untuk melatih kemampuan berpikir kreatif siswa.

\section{LATIHAN BERPIKIR KREATIF}

Contoh soal

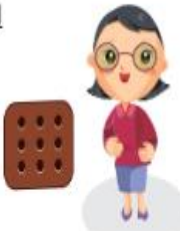

Ibu membeli sebuah biskuit berbentuk persegi, kemudian biskuit tersebut dipotong menjadi 2 bagian yang sama untuk dibagikan kepada dua anaknya. Gambarkan potongan biskuit itu yang menunjukkan setengah bagian untuk diberikan kepada masing-masing anak?

\section{Langkah Penyelesaian}

Biskuit yang masih utuh

Kemudian dipotong menjadi dua bagian yang same.

Jawaban :

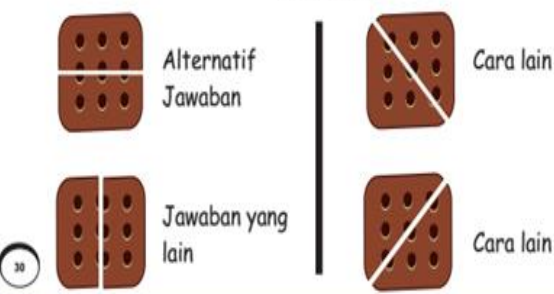

Gambar 5. Tampilan latihan soal 


\section{Halaman Penutup}

Halaman penutup ini merupakan bagian terakhir dari media cerita bergambar. Pada halaman ini berisi daftar pustaka yang digunakan dalam merancang media dan profil penulis yang menampilkan identitas penulis media cerita bergambar. Selanjutnya media cerita bergambar ditutup dengan sampul belakang yang berisi sinopsis produk yang ada di dalamnya.

\section{DAFTAR PUSTAKA}

https://all-free-download.com/free-vector/vector-food/ (diakses tanggal 9 Nopember 2019 pukul 15:00).

http://www.belajarcoreldraw.co/2011/07/tutorial-coreldraw-bikin-buku-pake.htm (diakses tanggal 7 Desember 2019

I Click Art, 2019. Designer's Collection [CD-ROM]. Vol. 02

Peraturan Menteri Pendidikan dan Kebudayaan Republik Indonesia No. 21 Tahun 2016 tentang Standar Isi Pendidikan Dasar dan Menengah.

Peraturan Menteri Pendidikan dan Kebudayaan Republik Indonesia No. 24 Tahun 2016 tentang Kompetensi Inti dan Kompetensi Dasar pada Pendidikan Dasar dan Menengah. Tip dan Trik Berkreasi dengan Corel draw X7. Yogyakarta: Penerbit Andi.

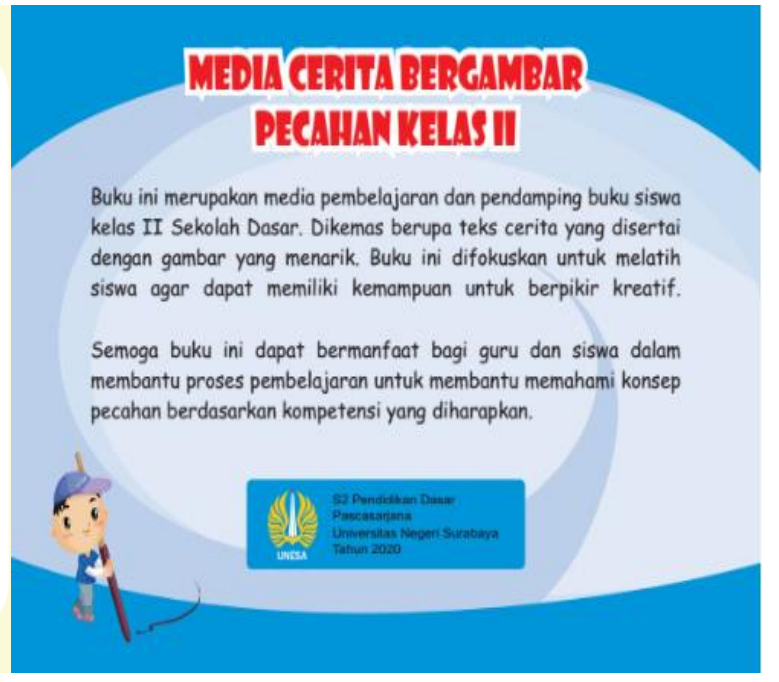

Gambar 6. Halaman penutup media cerita bergambar

\section{Pengembangan (develop)}

Tahap Develop (pengembangan) ini diawali dengan mengembangkan produk yang terdiri dari menghasilkan produk. Hasil media cerita bergambar ini akan digunakan untuk menguji kevalidan media berdasarkan pada penilaian para ahli, produk dihasilkan menggunakan aplikasi corel draw x7. Setelah merancang media dan menghasilkan drat awal, langkah selanjutnya yaitu melakukan validasi kepada para ahli untuk menguji kevalidan media. hasil validasi ahli media diperoleh hasil pada 17 aspek yang dinilai yaitu 9 aspek mendapat skor 4 (53\% sangat baik), 7 aspek mendapat skor 3 (41\% baik), dan 1 aspek mendapat skor 2 (6\% cukup baik). Berdasarkan kriteria minimal skor harus mendapatkan minimal baik, maka harus dilakukan revisi terhadap aspek 13 sehingga mendapat kriteria minimal baik. Revisi yang dilakukan adalah mengubah ukuran buku cerita bergambar dari A5 menjadi A4.

Selain itu, ahli media juga memberikan saran dan komentar pada lembar validasi yaitu pada halaman awal ada insert dialog yang ilustrasinya kurang sesuai dengan lainnya. Selain itu sudah baik dan dapat digunakan untuk penelitian. Maka revisi yang dilakukan adalah memperbaiki media yang dapat dijelaskan pada Tabel 2. 


\section{Tabel 1.}

Hasil Revisi Media Cerita Bergambar

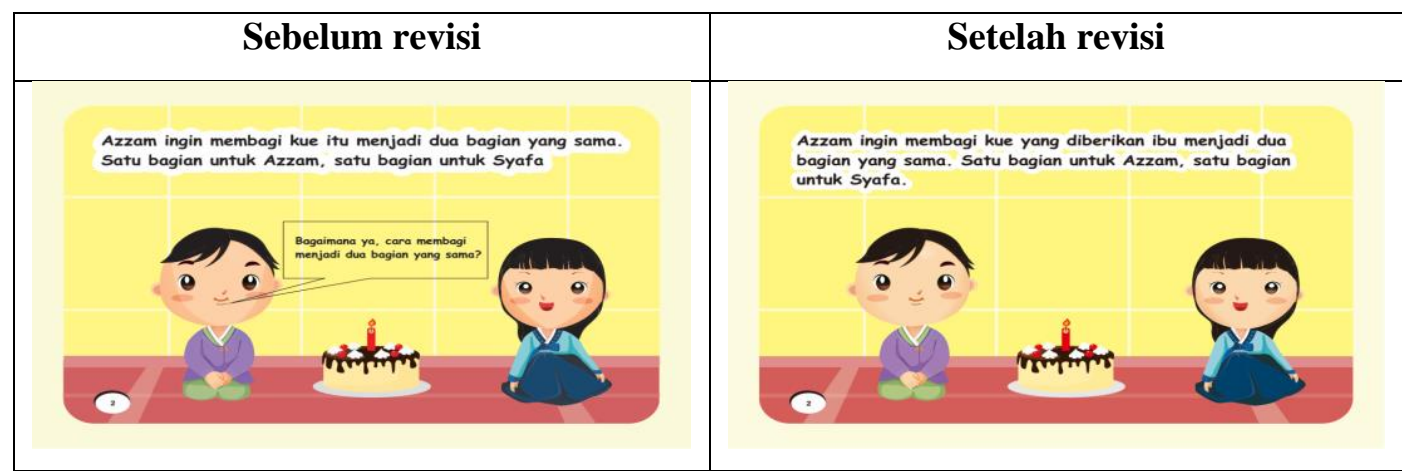

Hasil validasi ahli media yang kedua diperoleh hasil pada 17 aspek yang dinilai yaitu 11 aspek mendapat skor 4 (65\% sangat baik) dan 6 aspek mendapat skor 3 (35\% baik). Setelah validasi pertama dan melakukan revisi produk, pada validasi kedua media sudah valid dan dapat digunakan untuk penelitian. Maka dapat disimpulkan bahwa media cerita bergambar telah valid dan layak digunakan untuk penelitian.

Hasil validasi ahli materi terhadap media diperoleh hasil pada 20 aspek yang dinilai yaitu 14 aspek mendapat skor 4 (70\% sangat baik), 6 aspek mendapat skor 3 (30\% baik). Berdasarkan kriteria minimal baik, dengan demikian dapat disimpulkan bahwa media cerita bergambar telah valid dan layak digunakan untuk penelitian.

Hasil validasi RPP terdapat 73\% hingga 80\% termasuk kriteria sangat baik, 20\% hingga 27\% yang tergolong pada kriteria baik. Berdasarkan kriteria minimal baik, maka RPP dikatakan valid. Dengan demikian dapat disimpulkan bahwa RPP telah valid dan layak digunakan untuk penelitian.

Hasil validasi LKPD terdapat 56\% termasuk kriteria sangat baik, $44 \%$ yang tergolong pada kriteria baik. Berdasarkan kriteria minimal baik, maka instrumen LKPD ini dapat dikatakan valid dan layak digunakan untuk penelitian.

Tes Hasil Belajar yang telah dikembangkan telah divalidasi dan memenuhi kriteria minimal baik (skor 3). Maka dapat disimpulkan bahwa THB telah valid dan layak digunakan untuk penelitian. Tes berpikir kreatif yang telah dikembangkan telah memenuhi kriteria minimal baik (skor 3). Maka dapat disimpulkan bahwa tes berpikir kreatif ini valid dan layak digunakan untuk penelitian.

Hasil validasi angket respon siswa dari 10 aspek yang dinilai. Terdapat 8 aspek mendapatkan skor 4 (80\% sangat baik) dan 2 aspek mendapatkan skor 3 (20\% baik). Berdasarkan kriteria minimal baik, maka instrumen ini valid dan layak digunakan untuk penelitian.

Setelah melakukan validasi terhadap media dan perangkat serta merevisi sehingga menjadi draft final yang layak selanjutnya dilakukan diuji secara perorangan. Uji Coba Perorangan (one to one trial) ini dilakukan dengan memberikan angket lembar penilaian kepraktisan media kepada seorang guru dan 6 siswa di SDN Lontar II Surabaya. Berdasarkan rekapitulasi analisis data hasil lembar penilaian kepraktisan oleh guru ada 16 aspek yang dinilai. Terdapat 13 aspek mendapatkan skor 4 (81\% sangat baik) dan 3 aspek mendapatkan skor 3 (19\% baik). Berdasarkan kriteria kelayakan pada 
media dengan kategori minimal baik (skor 3), maka dapat disimpulkan bahwa media cerita bergambar dikatakan praktis dan mudah untuk digunakan dalam pembelajaran. Hasil lembar penilaian kepraktisan oleh 6 siswa secara keseluruhan, terdapat 70\% - 90\% termasuk kriteria sangat baik, 10\% $30 \%$ yang tergolong pada kriteria baik. Berdasarkan kriteria kepraktisan pada media dengan kategori minimal baik (skor 3), maka dapat disimpulkan bahwa media cerita bergambar dikatakan praktis dan mudah untuk digunakan siswa dalam pembelajaran.

Selanjutnya media yang telah diuji perorangan kemudian melakukan Uji Coba Kelompok Kecil (small group trial) dengan memberikan angket respon, tes berpikir kretaif, dan tes hasil belajar. Respon siswa dari 10 butir pertanyaan yang diajukan di atas $75 \%$ yaitu sebesar $85,50 \%$, sehingga menurut kriteria yang ditetapkan, maka dapat disimpulkan bahwa respon siswa terhadap pembelajaran menggunakan media cerita bergambar pada materi pecahan adalah positif.

Pelatihan kemampuan berpikir kreatif dilaksanakan pada tahap uji coba kelompok kecil dan tahap implementasi melalui pembelajaran menggunakan media cerita bergambar untuk melihat perubahan tingkat kemampuan berpikir kreatif siswa berdasarkan tingkat kemampuan berpikir kreatif dengan 2 indikator kemampuan berpikir kreatif yaitu kefasihan dan fleksibilitas dapat disajikan sebagai berikut.

Tabel 2.

Hasil Tes Berpikir Kreatif pada Tahap Uji Coba Kelompok Kecil

\begin{tabular}{|c|l|c|c|c|c|}
\hline \multirow{2}{*}{ No. } & \multirow{2}{*}{$\begin{array}{c}\text { Tingkat Kemampuan } \\
\text { Berpikir Kreatif }\end{array}$} & \multicolumn{2}{|c|}{ Pre Test } & \multicolumn{2}{c|}{ Post Test } \\
\cline { 3 - 6 } & Banyak Siswa & Persentase & Banyak Siswa & Persentase \\
\hline 1 & Sangat Kreatif & 0 & $0 \%$ & 4 & $20 \%$ \\
\hline 2 & Kreatif & 4 & $20 \%$ & 10 & $50 \%$ \\
\hline 3 & Cukup Kreatif & 13 & $65 \%$ & 5 & $25 \%$ \\
\hline 4 & Tidak Kreatif & 3 & $15 \%$ & 1 & $5 \%$ \\
\hline \multicolumn{2}{r|}{ Jumlah } & 20 & $100 \%$ & 20 & $100 \%$ \\
\hline
\end{tabular}

Berdasarkan tabel di atas dapat direpresentasikan skema perubahan tingkat kemampuan berpikir siswa sebelum pembelajaran menggunakan media cerita bergambar (pre-test) dan setelah pembelajaran menggunakan media cerita bergambar (post-test), sebagai berikut:

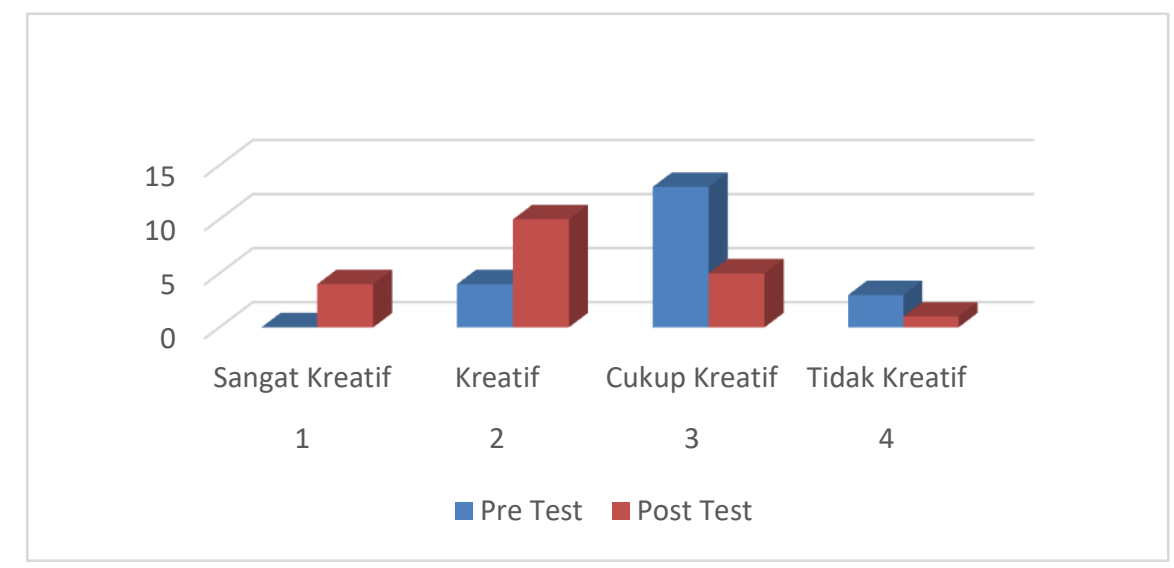

Gambar 7. Grafik kemampuan berpikir kreatif siswa pada tahap uji coba kelompok kecil 
Dari grafik di atas menunjukkan bahwa siswa mengalami peningkatan pada tingkat kemampuan berpikir kreatif siswa setelah diterapkan pembelajaran menggunakan media cerita bergambar. Persentase peningkatan kemampuan berpikir kreatif siswa pada tahap uji coba kelompok kecil telah dijelaskan pada bab IV sebesar $80 \%$.

Dengan demikian, berdasarkan hasil persentase perubahan tingkat kemampuan berpikir kreatif siswa pada tahap uji coba kelompok kecil setelah pembelajaran menggunakan media cerita bergambar dapat dikatakan positif karena $\geq 75 \%$ (Afiani, 2015).

Selanjutnya data tentang tes hasil belajar dimulai dengan menguji validitas dan reliabilitas butir soal, dan hasil THB. Dapat dipaparkan hasil tentang validitas dan reliabilitas butir soal tes hasil belajar pada tabel berikut ini.

Tabel 3.

Hasil Uji Validitas Butir Soal pada Tahap Uji Coba Kelompok Kecil

\begin{tabular}{ccccc}
\hline Butir Soal & $\begin{array}{c}\mathbf{r}_{\text {tabel }} \\
(\mathbf{N = 2 0})\end{array}$ & $\begin{array}{c}\mathbf{r}_{\text {hitung }} \\
\left(\mathbf{r}_{\mathbf{x y}}\right)\end{array}$ & Kriteria & Keterangan \\
\hline No.1 & 0,444 & 0,687 & Sedang & Valid \\
\hline No. 2 & 0,444 & 0,486 & Sedang & Valid \\
\hline No. 3 & 0,444 & 0,548 & Sedang & Valid \\
\hline No. 4 & 0,444 & 0,687 & Sedang & Valid \\
\hline No. 5 & 0,444 & 0,766 & Tinggi & Valid \\
\hline
\end{tabular}

Sumber: Data olahan peneliti, 2020

Hasil $r_{\text {hitung }}$ pada butir soal nomor 5 termasuk dalam kriteria tinggi. Karena butir soal nomor $1,2,3,4$, dan 5 diperoleh $r_{\text {hitung }}>r_{\text {tabel }}$, maka dapat disimpulkan bahwa setiap butir soal telah valid. Selanjutnya hasil reliabilitas butir soal THB dapat dilihat pada tabel 6 berikut ini.

Tabel 4.

Hasil Uji Reliabilitas Butir Soal pada Tahap Uji Coba Kelompok Kecil

\begin{tabular}{cccc}
\hline $\begin{array}{c}\mathbf{r}_{\text {tabel }} \\
(\mathbf{N = 2 0 )}\end{array}$ & $\begin{array}{c}\text { Reliabilitas Butir } \\
\text { Soal }\end{array}$ & Kriteria & Keterangan \\
\hline 0,444 & 0,583 & Sedang & Reliabel \\
\hline & & & Sumber: Data olahan peneliti, 2020
\end{tabular}

Hasil uji reliabilitas butir soal menunjukkan reliabilitas sebesar 0,583 termasuk pada kriteria sedang. Dikarenakan nilai reliabilitas butir soal lebih besar daripada $r_{\text {tabel }}$, maka dapat disimpulkan bahwa butir soal telah reliabel. Sesuai dengan tabel hasil THB, ketuntasan belajar secara klasikal dapat dihitung seperti berikut:

Persentase Ketuntasan Klasikal $=\frac{\text { Jumlah siswa yang tuntas }}{\text { Jumlah siswa yang mengikuti tes }} \times 100 \%$

$$
\begin{aligned}
& =\frac{17}{20} \times 100 \% \\
& =85 \%
\end{aligned}
$$

Berdasarkan penghitungan ketuntasan klasikal di atas, maka persentase ketuntasan belajar secara klasikal dapat dikatakan tuntas. 


\section{Implementasi (Implement)}

Setelah melakukan uji coba kelompok kecil, selanjutnya media yang telah dikembangkan diimplementasikan pada kelas sesungguhnya. Subyek pada tahap ini berjumlah 27 siswa diberikan angket respon, THB, dan TBK. Respon siswa pada tahap implementasi dari 10 butir pertanyaan yang diajukan memperoleh hasil rata-rata di atas $75 \%$ yaitu sebesar $90 \%$, sehingga menurut kriteria minimal baik, maka dapat disimpulkan bahwa respon siswa terhadap pembelajaran menggunakan media cerita bergambar pada materi pecahan adalah positif. Data hasil tes kemampuan berpikir kreatif siswa dapat disajikan pada tabel berikut ini.

\section{Tabel 5.}

Hasil Tes Berpikir Kreatif pada Tahap Implementasi

\begin{tabular}{|c|c|c|c|c|c|}
\hline \multirow{2}{*}{ No. } & \multirow{2}{*}{$\begin{array}{c}\text { Tingkat Kemampuan } \\
\text { Berpikir Kreatif }\end{array}$} & \multicolumn{2}{|c|}{ Pre Test } & \multicolumn{2}{|c|}{ Post Test } \\
\hline & & Banyak Siswa & Persentase & Banyak Siswa & Persentase \\
\hline 1 & Sangat Kreatif & 0 & $0 \%$ & 6 & $22 \%$ \\
\hline 2 & Kreatif & 7 & $26 \%$ & 16 & $59 \%$ \\
\hline 3 & Cukup Kreatif & 17 & $63 \%$ & 4 & $15 \%$ \\
\hline 4 & Tidak Kreatif & 3 & $11 \%$ & 1 & $4 \%$ \\
\hline & Jumlah & 27 & $100 \%$ & 27 & $100 \%$ \\
\hline
\end{tabular}

Berdasarkan tabel di atas dapat direpresentasikan skema perubahan tingkat kemampuan berpikir siswa sebelum pembelajaran menggunakan media cerita bergambar (pre-test) dan setelah pembelajaran menggunakan media cerita bergambar (post-test), sebagai berikut.

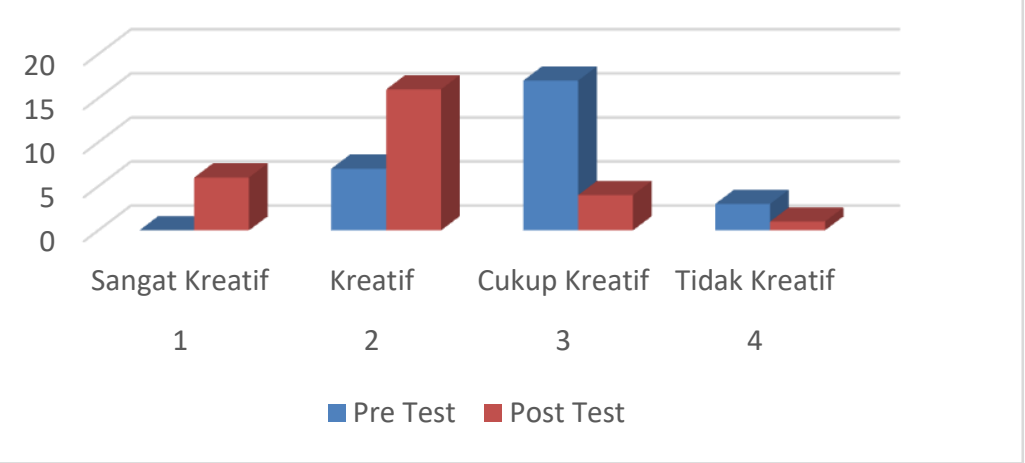

Gambar 8. Grafik kemampuan berpikir kreatif siswa pada tahap implementasi

Dari grafik di atas menunjukkan bahwa siswa mengalami peningkatan pada tingkat kemampuan berpikir kreatif setelah diterapkan pembelajaran menggunakan media cerita bergambar. Persentase peningkatan tingkat kemampuan berpikir kreatif pada tahap implementasi telah dijelaskan pada bab IV mengalami peningkatan sebesar $85 \%$.

Dengan demikian, berdasarkan hasil persentase perubahan tingkat kemampuan berpikir kreatif siswa pada tahap implementasi setelah pembelajaran menggunakan media cerita bergambar dapat dikatakan positif karena $\geq 75 \%$ (Afiani, 2015). 
Selanjutnya data tes hasil belajar pada tahap implementasi dapat dijelaskan melalui Tabel 6 berikut ini.

\section{Tabel 6.}

Hasil Uji Validitas Butir Soal pada Tahap Implementasi

\begin{tabular}{ccccc}
\hline $\begin{array}{c}\text { Butir } \\
\text { Soal }\end{array}$ & $\begin{array}{c}\mathbf{r}_{\text {tabel }} \\
(\mathbf{N = 2 7 )}\end{array}$ & $\begin{array}{c}\mathbf{r}_{\text {hitung }} \\
\left(\mathbf{r}_{\mathbf{x v}}\right)\end{array}$ & Kriteria & Keterangan \\
\hline No.1 & 0,381 & 0,665 & Sedang & Valid \\
\hline No. 2 & 0,381 & 0,569 & Sedang & Valid \\
\hline No. 3 & 0,381 & 0,457 & Sedang & Valid \\
\hline No. 4 & 0,381 & 0,772 & Tinggi & Valid \\
\hline No. 5 & 0,381 & 0,791 & Tinggi & Valid \\
\hline & & & Sumber: Data olahan peneliti, 2020
\end{tabular}

Berdasarkan hasil uji validitas butir soal pada tabel 4.25, dari 5 butir soal yang diujikan. Karena butir soal nomor $1,2,3,4$, dan 5 diperoleh $\mathrm{r}_{\text {hitung }}>\mathrm{r}_{\text {tabel }}$, maka dapat disimpulkan bahwa setiap butir soal dapat dinyatakan valid. Selanjutnya dihitung reliabilitas butir soal yang dapat disajikan pada tabel 9 berikut ini.

Tabel 7.

Hasil Uji Reliabilitas Butir Soal pada Tahap Implementasi

\begin{tabular}{cccc}
\hline $\begin{array}{r}\mathbf{r}_{\text {tabel }} \\
(\mathrm{N}=27)\end{array}$ & Reliabilitas Butir Soal & Kriteria & Keterangan \\
\hline 0,381 & 0,620 & Sedang & Reliabel \\
\hline & & Sumber: Data olahan peneliti, 2020
\end{tabular}

Hasil uji reliabilitas butir soal menunjukkan reliabilitas sebesar 0,620 termasuk pada kriteria sedang. Dikarenakan nilai reliabilitas butir soal lebih besar daripada $r_{\text {tabel }}$, maka dapat disimpulkan bahwa butir soal telah reliabel.

Sesuai dengan tabel hasil THB, ketuntasan belajar secara klasikal dapat dihitung seperti berikut: Persentase Ketuntasan Klasikal $=\frac{\text { Jumlah siswa yang tuntas }}{\text { Jumlah siswa } \text { yang mengikuti tes }} \times 100 \%$

$$
\begin{aligned}
& =\frac{24}{27} \times 100 \% \\
& =89 \%
\end{aligned}
$$

Berdasarkan penghitungan ketuntasan klasikal di atas, maka persentase ketuntasan belajar secara klasikal dapat dikatakan tuntas.

\section{Evaluasi (evaluate)}

Pada tahap evaluai terdiri dari evaluaasi formatif dan sumatif. Evaluasi formatif dilaksanakan di akhir kegiatan pada setiap empat tahap penelitian. Evaluasi yang dimaksudkan untuk memperbaiki media di setiap tahapnya. Masing-masing tahap dievaluasi dan direvisi untuk mendapatkan hasil media yang layak meliputi valid, praktis, dan efektif. Hasil evaluasi formatif telah dijabarkan pada masing-masing tahapan/fase di atas. Evaluasi sumatif diperoleh dari hasil data angket respon siswa pada tahap uji coba kelompok kecil mendapat hasil respon yaitu sebanyak $85,50 \%$, sedangkan pada tahap implementasi mendapat hasil respon 90\%. Dengan demikian, pembelajaran dengan menerapkan 
media cerita bergambar dikatakan positif pada tahap uji coba maupun implementasi. Hasil penilaian tes hasil belajar pada tahap uji coba yang mencapai ketuntasan dengan nilai KKM 75 sebanyak 17 dari 20 siswa atau 85\% tingkat ketuntasan kelas, sedangkan pada tahap implementasi yang mencapai ketuntasan dengan nilai KKM 75 sebanyak 24 dari 27 siswa atau 89\% tingkat ketuntasan kelas. Hasil dari tes berpikir kreatif siswa yang menunjukkan perubahan positif pada tahap uji coba sebesar $80 \%$, sedangkan pada tahap implementasi sebesar $85 \%$. Dengan demikian, dapat disimpulkan bahwa pembelajaran yang telah dilaksanakan dengan menerapkan media cerita bergambar adalah efektif.

\section{KESIMPULAN}

Berdasarkan diskusi hasil penelitian dan sesuai dengan tujuan yang diharapkan dalam penelitian ini, maka dapat ditarik dua kesimpulan berikut: (1) Pengembangan media cerita bergambar yang telah dilaksanakan mengikuti modifikasi model ADDIE dan media pembelajaran yang dihasilkan layak karena kriteria kevalidan, kepraktisan, dan keefektifan telah terpenuhi; (2) Kemampuan berpikir kreatif yang dimiliki siswa kelas II SD setelah mengikuti pembelajaran dengan menggunakan media cerita bergambar pada materi Pecahan mengalami perubahan positif ditandai dengan peningkatan yang signifikan. Kemampuan berpikir kreatif siswa pada tahap uji coba kelompok kecil mengalami kemajuan sebesar $80 \%$ dan pada tahap implementasi mengalami kemajuan sebesar $85 \%$.

Berdasarkan diskusi hasil penelitian dan pengalaman selama penelitian, maka peneliti dapat memberikan saran-saran sebagai berikut: (1) Media cerita bergambar pada materi pecahan ini dapat digunakan sebagai alternatif media pembelajaran konsep pecahan setengah, sepertiga, dan seperempat kelas II Sekolah Dasar untuk melatih kemampuan berpikir kreatif siswa; (2) Modifikasi model ADDIE ini dapat digunakan untuk penelitian pengembangan media pembelajaran topik lain di dalam pembelajaran matematika.

\section{DAFTAR PUSTAKA}

Afiani, K. D. A. (2015). Pengembangan Perangkat Pembelajaran Berbasis Pengajuan Masalah untuk Melatih Kemampuan Berpikir Kreatif Siswa Kelas IV SD pada Materi Sudut. Jurnal Kajian Pendidikan dan Hasil Penelitian, Vol. 1 No.1.

Branch, R. M. (2009). Instructional Design: The ADDIE Approach. New York: Springer Science adnd Business Media.

Mahmudi, A. (2009). Mengembangan Kemampuan Berpikir Kreatif Siswa Melalui Pembelajaran Topik Pecahan. Dipresentasikan dalam Seminar Nasional Aljabar, Pengajaran Dan Terapannya dengan tema Kontribusi Aljabar dalam Upaya Meningkatkan Kualitas Penelitian dan Pembelajaran Matematika untuk Mencapai World Class University yang diselenggarakan oleh Jurusan Pendi.

Maulida, N. (2018). Pengembangan bahan bacaan cerita bergambar berorientasi pendidikan karakter untuk pembelajaran membaca siswa kelas II SD. 6(1), 12-21. 
Nieveen, N., \& et.al. (1999). Design Approaches and Tools in Education and Training. Kluwer Academic Publishers.

Ozsezer, M. S. B., \& Canbazoglu, H. B. (2018). Picture in Children's Story Books: Children's Perspective. International Journal of Educational Methodology, 4(4), 205-217. https://doi.org/10.12973/ijem.4.4.205

Pehkonen, E. (1997). The State-of-Art in Mathematical Creativity. ZDM, 29. Diambil dari http://www.fiz.karlsruhe.de/fiz/publications/zdm

Siswono, T. Y. E. (2018). Pembelajaran Matematika Berbasis Pengajuan dan Pemecahan Masalah.

Siswono, T. Y. E., \& Rosyidi, A. H. (2005). Menilai Kreativitas Siswa dalam Matematika. Prosiding Seminar Nasional Matematika dan Pendidikan Matematika "Peranan Matematika dan terapannya dalam meningkatkan Mutu Sumber Daya Manusia Indonesia" di jurusan matematika FMIPA Unesa, 28 Pebruari 2005.

Sugiyono. (2018). Metode Penelitian Kuantitatif, Kualitatif, dan R\&D. Bandung: CV. Alfabeta. 